SHS Web of Conferences 12, 01009 (2014)

DOI: $10.1051 /$ shsconf $/ 20141201009$

(C) Owned by the authors, published by EDP Sciences, 2014

\title{
Romance of Experience, Satisfaction and Behavioral Intentions: An Empirical Examination of International Delegates in Academic Conferences
}

\author{
Faizan Ali $^{1}$, Kashif Hussain ${ }^{2}$, Neethiahnanthan Ari Ragavan ${ }^{3}$ \\ ${ }^{1}$ International Business School, Universiti Teknologi Malaysia, Kuala Lumpur, 54100, Malaysia \\ ${ }^{2,3}$ School of Hospitality, Tourism and Culinary Arts, Taylor's University, Selangor, 47500, Malaysia
}

\begin{abstract}
The growing attention placed on experiences can be regarded as a mega-trend, and has given currency to the proposition that experiences are important for consumer's self-perception and satisfaction with a specific visit. In order to assess this assumption, this study empirically examines the applicability of Pine and Gilmore's 'experience economy' concept and examines the impact of its four dimensions i.e., education, escapism, esthetics, and entertainment on delegates' satisfaction and behavioural intentions. Based on convenience sampling, 210 questionnaires are distributed to the delegates of 2 international academic conferences out of which 188 were deemed fit for further analysis ( $89 \%$ response rate). The results indicate that Pine and Gilmore's model can further our understanding of the experience market. However, the findings in contrast with previous studies show that different experiential dimensions influence the delegates' overall satisfaction in different contexts. For instance, the dimension of education has a relatively higher significant effect on the delegates' overall satisfaction and behavioural intentions in the context of international academic conferences. The theoretical and practical implications of this study are also discussed.
\end{abstract}

\section{Introduction}

Experience economy is used as an overarching concept encompassing a variety of industries whose purpose is to create experiences [1]. [2] coined the term 'experience economy' referring to the final phase of an economic progression where the focus is on staging experiences. This view indicates the importance of overall experiences in satisfaction of an individual with a given product or service [3]. Consequently, experience economy has evolved to be a mega-trend which can be observed across various industries [4]; which is attributed towards the need for consumers to be engaged and co-create the whole experience in different contexts [5].

Despite these invaluable conceptual works on the experience economy, empirical examinations on the subject have unfortunately been scarce [3-4,6]. [2] explicitly proposed four dimensions of experience education, escapism, esthetics, and entertainment which were later on operationalised by [7] and [6] in the context of bed and breakfast and cruise ships respectively. Further, there are very few studies that have examined the relationship between these experiential dimensions and other consequent variables (e.g., satisfaction, willingness to revisit, etc.) in other contexts of tourism [3-4]. 
Consequently, this paper aims to contribute to filling this void by empirically examining how different experiential dimensions influence international delegates' overall satisfaction and behavioural intentions in academic conferences, an integral part of business tourism.

Business tourism is one of the fastest growing tourism segments and is a very important sector [8]. This is the reason why many countries are now increasingly competing to get their share off this lucrative market [9]. As per Union of International Association, in 2011, the total number of meetings and conventions was over 10,000 held in 255 countries showing an increase of $63 \%$ since 2002 . Because of its huge impact on reviving the economy, many nations are trying to develop and sustain various dimensions of business tourism including academic conferences. Moreover, international delegates of these conferences are valuable assists for the tourism industry. Their attendance benefits conference organizers as well as the host locations. They bring multi-economic benefits to the host location through their expenditure on accommodation, food and beverages, local transportation and miscellaneous spending [10], making it an interesting segment to study.

\section{Literature Review}

\subsection{Experience Economy}

[2] explored the concept of experiences by coining the term, "experience economy", which is the final phase of economic progression that has developed from commodity, product and service economy. [2] defined experience as "events that engage individuals in a personal way" (p. 12); whereas [7] defined experiences as, "enjoyable, engaging, memorable encounters for those consuming these events" (p. 120). While discussing experience economy, [11] identified four realms of customer experiences including entertainment, education, esthetic and escapism. These four dimensions are differentiated across two axes i.e., the degree of customer involvement and the connection of customer with the surroundings [6]. The first dimension is entertainment which is developed when passive absorption is observed by the customer such as watching a theatre performance [7]. The second dimensions is esthetic where the customer has a passive participation and immersion in the experience. Examples for esthetic dimensions includes a beautiful arrangement of historical relics in a museum, an attractive servicescape or ambience in a resort hotel or experiencing the breath-taking scenery of Niagara Falls [4]. The third dimension is education which refers to an experience where the participant actively participates but is in absorption such as snorkelling, scuba diving or ski-schools. The fourth and the last dimension is escapism which happens when the participant is affecting the actual performances in the real or virtual environment for example, by rafting or playing in a casino [6]. To summarise, it can be stated that entertainment experience is about feeling, the educational experience learning, the esthetic experience presence, and the escapist experience doing influence customers' emotions and satisfaction levels $[4,6]$.

\subsection{Customer Satisfaction}

Literature has taken two approaches to define customer satisfaction. It is defined by [12] as " $a$ judgment that a product, or service feature, or the product or service itself, provides a pleasurable level of consumption-related fulfilment, including levels of under or over fulfilment" ( $\mathrm{p}$. 13). On the other hand [13] described satisfaction from a cognitive perspective as "a post-choice evaluative judgment concerning a specific purchase selection" (p. 497). However, [14] stated that customer satisfaction is more complex than could be explained by the cognitive evaluative process. Nowadays most researchers support the value of understanding customer satisfaction concepts from a broader perspective to capture the interplay between cognition and emotion [15]. Numerous researchers have studied customer satisfaction across hospitality industry. For instance, [16] used four emotions-laden items to study customer satisfaction. On the other hand, [17] pointed out that customer satisfaction is based on hospitality, accommodation, food and beverage, recreation and entertainment, supplementary 
services, security and safety, innovation and value-added services, transportation, location, and appearance, as well as on the more basic concerns of pricing and payment. A recent study by [18] pointed out that customer satisfaction is based on four factors i.e., reception, food and beverage, house-keeping and price. There is a high tendency for the critical attributes to receive compliments for good performance and vice versa. Consequently, satisfying customers is the ultimate goal of every business due to its potential impact on repeat purchasing behaviour and profits [19].

\subsection{Behavioural Intentions}

[20] stated that behavioral intentions ". . . signal whether customers will remain with or defect from the company" (p. 33). Similarly, [12] described behavioral intentions as "a stated likelihood to engage in a behavior"' (p. 28). These behavioral intentions are either favorable or unfavorable which are also referred to as 'approach-avoidance' by [21]. Favorable intentions include remaining loyal and recommending the service providers whereas the unfavorable intentions include customer defection [22-23]. Some scholars also postulated that behavioral intentions includes loyalty intentions [3, 24] and it is significant to study consumers' behavioral intentions as these are strong predictors of their actual behaviors $[3,25]$.

\subsection{Experience, Satisfaction and behavioural intentions}

It has been advised by [2] that customers' consumption experiences revolving around 4Es result in strong satisfaction and positive behaviours. A limited number of scholars have studied this phenomena and they support the positive impact of 4Es on consumer satisfaction [3, 26- 27]. In this context, [28] stated that a hedonic and entertaining experience that can enhance knowledge of the guests can end up with satisfaction and positive behaviours such as behavioural intentions etc. [7] and [6] also observed a significant relationship between the 4Es, satisfaction and loyal behaviour of guests in bed and breakfast and cruise ship industry respectively. Hence, it is hypothesised that;

$H 1$ (a): Educational experience of international delegates in academic conference influences their satisfaction significantly.

$H 1$ (b): Entertainment experience of international delegates in academic conference influences their satisfaction significantly.

$H 1$ (c): Esthetic experience of international delegates in academic conference influences their satisfaction significantly.

$H 1$ (d): Escapism experience of international delegates in academic conference influences their satisfaction significantly.

$H 2$ (a): Educational experience of international delegates in academic conference influences their behavioural intentions significantly.

$H 2$ (b): Entertainment experience of international delegates in academic conference influences their behavioural intentions significantly.

$H 2$ (c): Esthetic experience of international delegates in academic conference influences their behavioural intentions significantly.

$H 2$ (d): Escapism experience of international delegates in academic conference influences their behavioural intentions significantly

The positive relationship between customer satisfaction and behavioural intentions has generally been recognized in previous tourism studies [19]. [12] states satisfaction has been a predictor of customers' behavioral intentions including revisit intentions and intention to recommend. The link between customer satisfaction and behavioural intentions was also studied and verified by [19] across Chinese resort hotels. Findings from the study of [29] also support the existence of positive link between customers' satisfaction and their behavioural intentions. Based on these empirical and theoretical arguments, it is hypothesized that; 
H3: Satisfaction of international delegates in academic conference influences their behavioural intentions significantly.

\section{Research Methodology}

The data was collected from international delegates at two international academic conferences held at a Private University in Kuala Lumpur, Malaysia during May, 2014 over three days. A convenient sampling technique was used to select the sample. Questionnaire was developed based on previous research [3-4, 7, 22] and used 5-point Likert scale. A total of 210 questionnaires were distributed to these delegates out of which 188 were returned and deemed fit for analysis, resulting in an effective response rate of $89 \%$. Out of these 188 respondents, $56 \%$ were male whereas $44 \%$ were female. $32 \%$ were having age below 30 years, $50 \%$ were between 31 and 50 years and $18 \%$ were older than 50 years. The data was analysed using SPSS and AMOS. To assess the measurement model, the research conducted a confirmatory factor analysis (CFA) with reliability and construct validity checks. To assess the overall fit of the proposed model and test hypotheses, structural equation modelling (SEM) was conducted as recommended by [30].

\section{Results}

All standardized factor loading of each construct was high (above .720) that ensured the convergent validity. Composite reliability for six latent constructs was between .730 and .867 that ensured the internal consistency (See Table 1). The CFA showed appropriate goodness-of-fit indices $\left(\chi^{2}=396.820\right.$, $d f=237, \chi^{2} / d f=1.674, p<0.001, \mathrm{RMSEA}=.059, \mathrm{CFI}=.928, \mathrm{GFI}=0.901$ and $\left.\mathrm{TLI}=0.928\right)$.

Table 1: Validity and Reliability for Constructs

\begin{tabular}{|c|c|c|c|}
\hline Variables and Items & Loadings & AVE & $\mathrm{CR}$ \\
\hline \multicolumn{4}{|l|}{ Education } \\
\hline This conference increased my knowledge & 0.889 & & \\
\hline I learned a lot during this conference & 0.861 & 0.766 & 0.867 \\
\hline \multicolumn{4}{|l|}{ Entertainment } \\
\hline I enjoyed various activities/sessions at the conference & 0.806 & & \\
\hline Various activities/sessions at the conference were entertaining & 0.731 & 0.592 & 0.742 \\
\hline \multicolumn{4}{|l|}{ Esthetics } \\
\hline The physical setting at the conference was very attractive & 0.723 & & \\
\hline $\begin{array}{l}\text { The physical setting at the conference strengthened my overall } \\
\text { experience }\end{array}$ & 0.792 & 0.575 & 0.730 \\
\hline \multicolumn{4}{|l|}{ Escapism } \\
\hline The got carried away by various activities at the conference & 0.828 & & \\
\hline I totally forgot about my daily routine & 0.841 & 0.696 & 0.821 \\
\hline \multicolumn{4}{|l|}{ Satisfaction } \\
\hline Overall, I am satisfied with my visit to this conference & 0.827 & & \\
\hline $\begin{array}{l}\text { Overall, I am satisfied with the food service quality provided } \\
\text { at this conference }\end{array}$ & 0.836 & 0.691 & 0.818 \\
\hline \multicolumn{4}{|l|}{ Behavioural Intentions } \\
\hline I will revisit this conference in the future & 0.862 & & \\
\hline I would recommend this conference to others. & 0.729 & 0.637 & 0.777 \\
\hline Notes: $x^{2}=40.836$, CMIN $/ \mathrm{df}=1.047$, GFI $=0.966$, CFI $=$ & $8, T L I=0$ & RMSE & 0.016 \\
\hline
\end{tabular}


The average variance extracted (AVE) from all constructs exceeded the cut-off criterion of .5, and were greater than the squared correlations between any pair of constructs (See Table 2).

Table 2: Discriminant Validity

\begin{tabular}{lcccccc}
\hline & Education & Entertainment & Esthetics & Escapism & Satisfaction & $\begin{array}{c}\text { Behavioural } \\
\text { Intentions }\end{array}$ \\
\hline Education & $\mathbf{0 . 8 7 5}$ & & & & & \\
Entertainment & 0.709 & $\mathbf{0 . 7 6 9}$ & & & & \\
Esthetics & 0.656 & 0.681 & $\mathbf{0 . 7 5 8}$ & & & \\
Escapism & 0.672 & 0.629 & 0.983 & $\mathbf{0 . 8 3 4}$ & & \\
Satisfaction & 0.664 & 0.575 & 0.501 & 0.547 & $\mathbf{0 . 8 3 1}$ & \\
Behavioural & 0.662 & 0.708 & 0.506 & 0.465 & 0.403 & $\mathbf{0 . 7 9 8}$ \\
Intentions & & & & & & \\
\hline
\end{tabular}

Since all these figures and measurement ensure reliability and validity of the measurement items, therefore, this research tested the same measurement model for further testing of the structural model and hypotheses. The structural model also showed appropriate goodness-of-fit indices $\left(\chi^{2}=40.836\right.$, $d f=39, \chi^{2} / d f=1.047, \mathrm{RMSEA}=.016, \mathrm{CFI}=.998, \mathrm{GFI}=0.966$ and TLI $\left.=0.997\right)$. The result in Table 3 showed that all four dimensions of experience had positive and significant impact on international delegates' satisfaction $\left(\mathrm{R}^{2}=0.54\right)$. Moreover, it was also observed that all four dimensions of experience and satisfaction with the academic conferences can influence international delegates' behavioral intentions $\left(\mathrm{R}^{2}=0.52\right)$. Hence, all the hypotheses were accepted.

Table 3: Results of the Structural Model

\begin{tabular}{llccc}
\hline \multicolumn{2}{l}{ Hypothesis } & $\begin{array}{c}\text { Standard } \\
\text { Beta }\end{array}$ & $\begin{array}{c}\text { T } \\
\text { Statistics }\end{array}$ & Decision \\
\hline $\mathrm{H} 1 \mathrm{a}$ & Educational experience $\rightarrow$ Satisfaction & 2.482 & $5.416^{*}$ & Supported \\
$\mathrm{H} 1 \mathrm{~b}$ & Entertainment experience $\rightarrow$ Satisfaction & 0.821 & $6.532^{*}$ & Supported \\
$\mathrm{H} 1 \mathrm{c}$ & Esthetic experience $\rightarrow$ Satisfaction & 1.422 & $1.968^{* *}$ & Supported \\
$\mathrm{H} 1 \mathrm{~d}$ & Escapism experience $\rightarrow$ Satisfaction & 0.126 & $8.749 *$ & Supported \\
$\mathrm{H} 2 \mathrm{a}$ & Educational experience $\rightarrow$ Behavioral Intentions & 1.684 & $8.514^{*}$ & Supported \\
$\mathrm{H} 2 \mathrm{~b}$ & Entertainment experience $\rightarrow$ Behavioral Intentions & 0.143 & $9.736^{*}$ & Supported \\
$\mathrm{H} 2 \mathrm{c}$ & Esthetic experience $\rightarrow$ Behavioral Intentions & 1.032 & $4.482^{*}$ & Supported \\
$\mathrm{H} 2 \mathrm{~d}$ & Escapism experience $\rightarrow$ Behavioral Intentions & 0.588 & $3.302^{*}$ & Supported \\
$\mathrm{H} 3$ & Satisfaction $\rightarrow$ Behavioral Intentions & 1.032 & $1.966^{* *}$ & Supported \\
\hline$* * \mathrm{p}<0.05 * \mathrm{p}<0.01$ & & & \\
\hline
\end{tabular}

\section{Conclusion and Implications}

In today's intensely competitive market, it is generally assumed that the key to gaining an advantage lies in creating high-quality experiences that will, in turn, lead to positive emotions and loyal customers $[19,31]$. These relationships are acknowledged in various facets of hospitality and tourism industry. However, studies focusing on experience to elicit satisfaction and shape behavioral intentions in the context of academic conferences are scant. Therefore, this study aimed to examine how different experiential dimensions influence international delegates' overall satisfaction and behavioural intentions in academic conferences. This study adopts Pine and Gilmore's model of the four dimensions of experiences. Their model appears to be a useful framework to understand 
preferences of international delegates in an academic conference context where four experiential dimensions are shown to have significant effects on delegates' satisfaction and behavioural intentions. This study suggests that an evaluation of an experience based on the senses of feeling, learning, being, and doing may be an appropriate tool. Moreover, there are implications for how organizers within the business tourism industry should think in regard to creating and developing their products and services. In order to meet the market needs and demands, it is important to create and "stage" experiences so that they capture the essence of the four dimensions.

Structural equation modelling was used to test the hypotheses and the findings revealed that all four dimensions of experience had positive and significant impact on international delegates' satisfaction and behavioural intentions. Moreover, it was also observed that satisfaction with the academic conferences can influence international delegates' behavioral intentions. These findings were consistent with previous studies [3, 19, 32-33]. The findings show more specifically that the dimensions of education and esthetics effect the international delegates' level of satisfaction and behavioural intentions. These findings imply that experiences need to be created and staged depending on their associated contexts.

The results of this study generate some useful practical implications as well. Experience economy is a mega-trend implying an increased emphasis on staging of experiences as a source of added value $[2,34]$. The results from this study show that different dimensions of experience significantly influence delegates' level of satisfaction. Service providers and organizers in business tourism can, therefore, use these dimensions and their respective measurement scales to assess how well they have met the customer's expectations. Constant focus on measuring customer expectation and accordingly staging experiences are crucial for industries where it is difficult to determine what visitors expect before they come. Hence, understanding of how to create value in these type of industries through experiences is very critical for the organizers. Moreover, it is also important to focus on highlighting the elements which hold more weightage towards delegates' assessment of their overall experience. For instance, educational and esthetic aspects are relatively more important for international delegates in an academic conference. Hence, it should be ensured that the conference overall provides opportunities to develop and enhance knowledge and learning of the delegates. Organizers of academic conferences should focus on arranging various workshops and sessions to facilitate learning process of the delegates. Moreover, all of these sessions and workshops should be arranged in a very attractive esthetic environment. It is not an established fact that an event has to contain elements from all four dimensions for it to be a compelling experience. Therefore, it is essential that the producers have knowledge of which elements they should develop based on the context.

\section{Limitations and Future Research Suggestions}

Although the results of the current study have shed light on several important issues, some limitations need to be considered in future research. Since convenience sampling was used in this study, results cannot be generalized. For instance the findings should be interpreted with caution when applied to different types of conferences, events or different industries. Future research should examine the proposed relationships in other industries with a larger sample size.

\section{References}

1. Flagestad, Opplevelsesøkonomien på vei [The experience economy on the way]. Magma, 9, 3, 81-90 (2006)

2. J. Pine, J. H. Gilmore, The experience economy. (Boston, MA: Harvard Business School, 1999)

3. F. Ali, K. Hussain, R. Omar. An Assessment of Service Experience, Emotions and Behavioral Intentions in Resort Hotels. In Nair, V., Hussain, K., Mura, P., Hui, K.H.K., Ragavan, N.A. (Eds). Breaking Barriers - Shifting Gears - Proceedings of the 12th APacCHRIE Conference 2014, Kuala Lumpur, Malaysia: Taylors University (2014) 
4. M. Mehmetoglu, M. Engen. Pine and Gilmore's Concept of Experience Economy and Its Dimensions: An Empirical Examination in Tourism, Journal of Quality Assurance in Hospitality \& Tourism, 12, 4, 237-255 (2011)

5. E. Binkhorst, T.D. Dekker. Agenda for co-creation tourism experience research. J. Hosp. Mark. Manag, 18, 311-327 (2009)

6. S. Hosany, M. Witham. Dimensions of Cruisers' Experiences, Satisfaction, and Intention to Recommend. J. Of Travel Res, 49, 3, 351-364 (2009)

7. H. Oh, A. Fiore, M. Jeoung. Measuring experience economy concepts: tourism applications, J. Of Travel Res, 46, 2, 119-132 (2007)

8. H.Q. Zhang, V. Leung, H. Qu. A refined model of factors affecting convention participation decision-making. Tourism Manage, 28, 4, 1123-1127 (2007)

9. Y.-P. Wei, Y.-C. Huang. The Impact of Food Quality on Foodservice Satisfaction at International Conferences, J. of Conv \& Event Tour. 14, 3, 252-269 (2013)

10. D. Severt, Y. Wang, P.-J. Chen, D. Breiter. Examining the motivation, perceived performance, and behavioral intentions of convention attendees: Evidence from a regional conference. Tourism Manage, 28, 2, 399-408 (2007)

11. B.J. Pine, J.H. Gilmore. Welcome to the experience economy. Harvard Bus. Rev. 76, 97-105 (1998)

12. R.L. Oliver. Satisfaction: A behavioral perspective on the consumer. (New York: McGraw- Hill, 1997)

13. R. Day. Modeling Choices among Alternative Responses to Dissatisfaction. Advances in Consumer Research, 11, 496-499 (1984)

14. G.A. Churchill, C. Surprenant. An investigation into the determinants of customer satisfaction. J. Mar. Res. 19, 491-504 (1982)

15. J.C. Anderson, D.W. Gerbing. Structural equation modeling in practice: a review and recommended two-step approach. Psyc. Bul. 103, 3, 411-423 (1988)

16. Martin, M. O'Neill, S. Hubbard, A. Palmer. The role of emotion in explaining consumer satisfaction and future behavioural intentions. J. Serv. Mark, 22, 3, 224-236 (2008)

17. J. Xu, A. Chan. Service Experience and Package Tours, Asia Pac J Tour Res, 15, 2, 177-194 (2010)

18. A. Boswijk, T. Thijssen, E. Peelen. The experience economy: A new perspective. (Amsterdam: Pearson Education Benelux, 2007)

19. J. Teixeira, L. Patricio, N.J. Nunes, L. Nobrega, R.P. Fisk, L. Constantine. Customer experience modeling: from customer experience to service design. J. Serv. Res. 23, 3, 362 - 376 (2012)

20. R. Westbrook, R. Oliver. The dimensionality of consumption emotion patterns and consumer satisfaction. J. Con. Res. 18, 1, 84-91 (1991)

21. W. Poon, K.L. Low. Are travelers satisfied with Malaysian hotels? Int. J. Cont. Hosp. Manag., 17, 3, 217-227 (2005)

22. M. Amin, Z. Yahya, W.F.A. Ismayatim, S.Z. Nasharuddin, E. Kassim. Service quality dimension \& customer satisfaction: An empirical study in the Malaysian hotel industry. Ser. Mark. Q. 34, 2, 115-125 (2013)

23. F. Ali, M. Amin. The influence of physical environment on emotions, customer satisfaction and behavioural intentions in Chinese resort hotel industry. Paper presented at the KMITL-AGBA Conference Bangkok, 15-17/June (2013), Thailand, available at: https://www.academia.edu/5452598/The_Influence_of_Physical_Environment_on_Emotions_Cu stomer_Satisfaction_and_Behavioural_Intentions_in_Chinese_Resort_Hotel_Industry (accessed $9^{\text {th }}$ May, 2014)

24. V.A. Zeithaml, L.L. Berry, A. Parasuraman. The behavioral consequences of service quality, J. of Mark. 60, 2, 31-46 (1996)

25. A. Mehrabian, J.A. Russell. An Approach to Environmental Psychology. (England: The MIT Publisher, 1974) 
26. F. Ali, R. Omar, M. Amin. An examination of the relationships between physical environment, perceived value, image \& behavioural Intentions: A SEM approach towards Malaysian resort hotels. J. Hot. Tour. Manag. 27, 2, 9-26 (2013)

27. R. Ladhari. Service quality, emotional satisfaction, and behavioural intentions: A study in the. Manag. Serv. Qual., 19, 3, 308 - 331 (2009)

28. H. Han, W. Kim. Outcomes of Relational Benefits: Restaurant Customers' Perspective. J. Travel Tour. Mark. 26, 8, 820-835 (2009)

29. H. Han, K. Ryu. The roles of the physical environment, price perception, and customer satisfaction in determining customer loyalty in the family restaurant industry. J. Hosp. Tour. Res, 33, 4, 487-510 (2009)

30. J.H. Gilmore, B. Pine. Differentiating hospitality operations via experiences: Why selling services is not enough. Cornell Hotel Restaur Adm Q. 43, 3, 87-96 (2002)

31. D.L. Quadri-Felitti, A.M. Fiore. Destination loyalty: Effects of wine tourists' experiences, memories, and satisfaction on intentions. Tour. Hosp. Res. 13, 1, 47-62 (2013)

32. V.W.S. Tung, J.R.B. Richie. Exploring the essence of memorable tourism experiences. Ann. Tourism. Res, 48, 4, 1367-1386 (2011)

33. J. Lin, H. Liang. The influence of service environments on customer emotion and service outcomes. Manag. Serv. Qual, 21, 4, 350 - 372 (2011) 